\title{
Composition and diversity of Trichoptera (Insecta) larvae communities in the middle section of the Jacuí River and some tributaries, State of Rio Grande do Sul, Brazil ${ }^{1}$
}

\author{
Marcia R. Spies ${ }^{2}$, Claudio G. Froehlich ${ }^{2} \&$ Carla B. Kotzian ${ }^{3}$
}

1. Study subsidized by Dona Francisca Energética S.A. (DFESA).

2. Departamento de Biologia, FFCLRP/USP. Av. Bandeirantes, 3900, 14040-901 Ribeirão Preto, SP. (marciaspies@gmail.com; cgfroeh@usp.br)

3. Departamento de Biologia, UFSM (Campus), Av. Roraima s/n, 97105-900 Santa Maria, RS. (modrizralok@hotmail.com)

\begin{abstract}
The taxonomic composition and diversity of Trichoptera larvae communities were studied in four lotic sites in central region of State of Rio Grande do Sul. Sampling was done monthly from June, 2001 to May, 2002 in four sites located at the middle section of Jacuí River (Point 4) and in three tributaries (Carijinho River - Point 1; Lajeado da Gringa - Point 2 and Lajeado do Gringo - Point 3 ), with a Surber sampler. The total number of larvae collected was 29,143 , belonging to 25 genera distributed in nine families; twenty of these genera are new records for the State. The highest abundance was found at Point 2 ( $\mathrm{n}=12,547)$. The highest standardized richness, for a 1,177 specimens sample chosen by chance, was recorded at Point 1, followed by Point 4 (17.7 and 16 genera, respectively). The highest diversity was found at Point 1 , and the lowest at Point $3\left(\mathrm{H}^{\prime}=1.31\right.$ and $\mathrm{H}^{\prime}=0.77$, respectively). Point 1 had the lowest anthropic influence and the best preserved riparian vegetation, while Point 3 presented the highest anthropic impact, and a very reduced riparian vegetation. The diversity of Trichoptera observed in this study is low, compared to the estimated maximum theoretical diversity. Low diversity values are related to the low evenness, since the richness was relatively high. The Trichoptera larvae communities seem to be related to the food availability and physical features (riparian vegetation and anthropic influence) of the study sites.
\end{abstract}

KEYWORDS. Faunistic composition, larvae assemblage, caddisflies, physical features, State of Rio Grande do Sul.

RESUMO. Composição e diversidade de comunidades de larvas de Trichoptera (Insecta) no trecho médio do rio Jacuí e alguns tributários, Estado do Rio Grande do Sul, Brasil. A composição taxonômica e a diversidade de comunidades de larvas de Trichoptera foram estudadas em quatro ambientes lóticos na região central do Estado do Rio Grande do Sul. As amostras foram coletadas mensalmente de junho de 2001 a maio de 2002 em quarto pontos, localizados no trecho médio do Rio Jacuí (Ponto 4) e em três tributários (Rio Carijinho - Ponto 1; Lajeado da Gringa - Ponto 2 e Lajeado do Gringo - Ponto 3), com amostrador de Surber. O número total de larvas coletado foi 29.143, pertencentes a 25 gêneros distribuídos em nove famílias; vinte destes gêneros constituem registros novos para o Estado. A maior abundância foi encontrada no Ponto $2(\mathrm{n}=12.547)$. A maior riqueza padronizada, para uma amostra de 1.177 espécimes retirados ao acaso, foi registrada no Ponto 1, seguida pelo Ponto 4 (17,7 e 16 gêneros, respectivamente). A maior diversidade foi encontrada no Ponto 1 e a menor no Ponto $3\left(\mathrm{H}^{\prime}=1,31\right.$ e $\mathrm{H}^{\prime}=0,77$, respectivamente). O Ponto 1 possui a menor influência antrópica e a vegetação ripária melhor conservada, enquanto o Ponto 3 apresentou o maior impacto antrópico e a vegetação ripária muito reduzida. A diversidade de Trichoptera observada neste estudo foi baixa, comparada com a diversidade teórica máxima estimada. Os baixos valores de diversidade registrados estão relacionados à baixa equidade, pois a riqueza foi relativamente alta. As comunidades de larvas de Trichoptera parecem estar relacionadas com a disponibilidade alimentar e as características físicas (vegetação ripária e influência antrópica) dos ambientes estudados.

PALAVRAS-CHAVE. Composição faunística, taxocenose de larvas, Trichoptera, características físicas, Estado do Rio Grande do Sul.

Trichopteran larvae are important in food webs of running waters, both because of the abundance of some species as due to the diversity of niches they occupy (ANGRISANO, 1995b; 1998). Silk production and the related behavioral adaptations led to high levels of taxonomic and ecological diversification (MACKAY \& WigGINS, 1979). Silk is used for many purposes (e.g., retreat construction, collecting nets, portable cases and the anchoring line of predators), allowing a more refined choice of habitats and food resources. As a result, the larvae present a strong potential as bioindicators (WIGGINS \& MACKAY, 1978).

Diversity and richness of the caddisfly fauna of an area are mostly related to the types of aquatic habitats present. In general, mountainous areas, with swift flowing waters, sustain a larger diversity than areas with a more uniform relief (FLINT, 1982). Heterogeneity and productivity of an environment, among other factors, determine the number of species that can live there. Successful communities depend on the complex interactions between species and food resources (Janzen, 1976, apud MACKAY \& WigGins, 1979).

Brazil has a vast hydrographic system but few surveys of lotic macroinvertebrates have been made, in part due to difficulties in taxonomic identification of immatures (OliveIRA \& FroeHLich, 1997a). Recently the interest on the study of Trichoptera has been growing, including ecological works (e.g. Oliveira \& Froenlich, 1996, 1997b; Oliveira et al., 1999; Oliveira \& BisPo, 2001; Huamantinco \& Nessimian, 1999; Bispo et al., 2004). Some of these works (DinIz-FiLHo et al., 1998; BisPo et al., 2004) have discussed the role of some physical features of the habitat, such as canopy cover and anthropic influence, in the Trichoptera larvae distribution in streams, when the chemical features of the water are not limiting to fauna survival.

Studies on caddisfly larvae in the State of Rio Grande do Sul are almost absent. There are only a few articles that refer to the macroinvertebrate communities 
of Sinos River basin (STERnERT et al., 2002; SANTOs et al., 2003) and of Tainhas and Taquara streams (BuENo et al., 2003), all located in the northeast of the state. Here a survey of the Trichoptera larvae of the central area of the state is presented, considering: 1) the taxonomic composition, at genus level, of Trichoptera assemblage in the middle course of Jacuí River and some tributaries; 2 ) the monthly variation in abundance of the genera between June 2001 and May 2002; 3) local diversity and its monthly variation, and the total diversity.

\section{MATERIAL AND METHODS}

The middle course of Jacuí River is located in the transition zone between the physiographic regions of the Northeastern Lower Slope and Central Depression, with elevations varying from 50 to $500 \mathrm{~m}$ (PEREIRA et al., 1989). According to Köppen's classification the climate is Cfa, humid subtropical with hot summer or warm and rainy temperate.
Rainfall is regularly distributed along the year; the annual rainfall ranging from 1,500 to $1,750 \mathrm{~mm}$ (PEREIRA et al., 1989). A Deciduous Seasonal Forest was the original vegetation, now mostly destroyed and represented by small fragments, secondary growth and riparian forest distributed sparsely along rivers and in mountain slopes (DuRLo et al., 1982; LONGHI et al., 1982; MARCHIORI et al., 1982).

In 2000 the Jacuí River was dammed for hydroelectric purposes (Dona Francisca Power Station, UHDF, 2926'50" S; 5316'50" W). The reservoir flooded 1,337 ha in six municipalities, contributing to the environmental alterations in the region.

Four sampling points were chosen, one in Jacuí River and three in left margin tributaries (Fig. 1) belonging to different municipalities, all affected by the dam. The hydrologic classification of the rivers follows STRAHLER (1957).

Point 1: Carijinho River (29²0’32” S; 5309'58”'W), at an elevation of $111 \mathrm{~m}$, a 4th order tributary, located in Arroio do Tigre Municipality. In some places, stones in

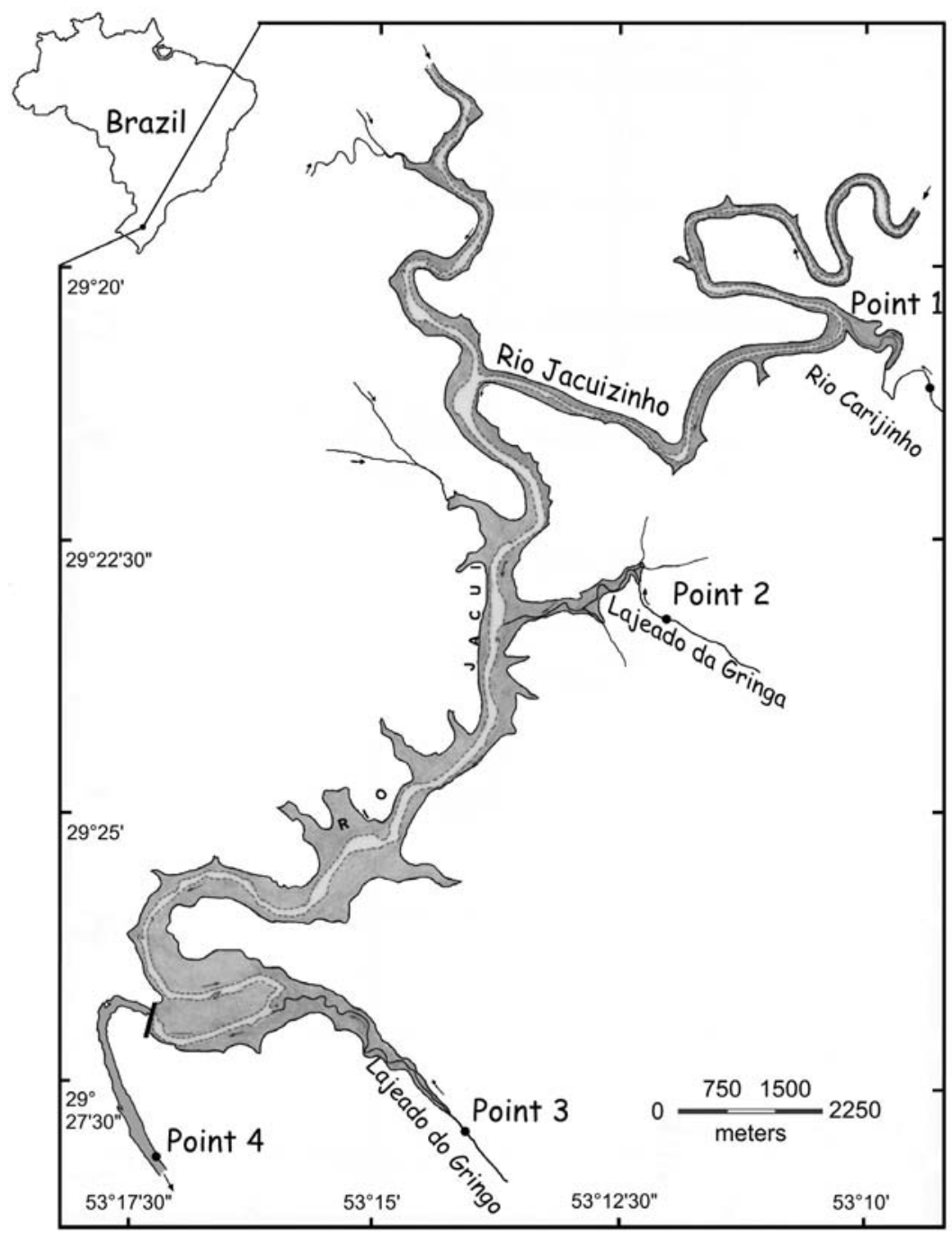

Fig. 1. Map of the study site, indicating the four sampling points in the River Jacuí middle section and in three tributaries, State of Rio Grande do Sul (RS). The central tracing represents the former river and the dark spotting represents the area flooded by the Dona Francisca dam. 
the river are covered with Podostemum Michaux (Podostemaceae).

Point 2: Lajeado da Gringa (29²2' 57' S; 5312'08' $\mathrm{W})$, at an elevation of $100 \mathrm{~m}$, a 3rd order tributary, located in Ibarama Municipality. Many stones in the river are covered with Podostemum.

Point 3: Lajeado do Gringo (29²8'03'' S; $53^{\circ} 13$ ' $28^{\prime \prime} \mathrm{W}$ ), at an elevation of $136 \mathrm{~m}$, a 4th order tributary, located in Ibarama Municipality. The point, placed near a farm house, is very affected by human activities (sewage, domestic animals).

Point 4: Jacuí River (29²8'45” S; 5316’51'” W), at an elevation of $70 \mathrm{~m}$, in a 7 th order stretch in Agudo Municipality, ca. $2 \mathrm{~km}$ downstream from the dam. In some months, collections were made in a bay formed during high waters.

For the degree of canopy cover and degree of anthropic influence scales from 1 to 3 were set as follows, based on a subjective evaluation: 1, low; 2, medium; 3 , high (OliveIRA et al., 1999). For turbidity, a scale from 1 - low to 2 - high, was based on a subjective evaluation (Tab. I).

The larvae were collected monthly from June 2001 to May 2002 with a Surber sampler (area of $0.36 \mathrm{~m}^{2}$ and $1 \mathrm{~mm}$ mesh). At each point three units were collected in riffles in the channel, except at Point 4, where samplings were made in the left margin, in shallow water. Macrophytes present on stones in the sampler area were scraped off and collected. The collected material was fixed and kept in $80 \%$ ethyl alcohol. Sorting, identification and counting of specimens were done under a stereomicroscope (or microscope, when needed). For family and genus-level identifications the keys of Angrisano (1995b), ANGrisano \& KоROB (2001) and WigGins (1996) and the articles of ANGRISANO (1993, 1995a); Flint (1963, 1972); Flint \& WALLACE (1980); FLINT \& Bueno-Soria (1982) and Pes \& HAMAdA (2004) were used.

Larvae of Glossosomatidae, due to their small size, had to be identified under a microscope and, due to the large number of specimens collected $(16,230)$, a subsampling procedure was used, ca. $10 \%$ of specimens of each sample being chosen randomly and then extrapolated to the total number. Very small larvae of the tribe Leucotrichiini (Hydroptilidae) could not be recognized to genera. Their numbers were apportioned to genera based on the percentages of the larger specimens.

Voucher specimens are deposited in the Invertebrate Collection of the Zoology Section of the Department of Biology, Federal University of Santa Maria (UFSM), State of Rio Grande do Sul, and in the Museum of Zoology, University of São Paulo (MZSP), State of São Paulo.

The diversity of genera of each point and the total diversity were estimated by Shannon-Wiener Index, using

Table I. Physical characterization of the four sampling points in the Jacuí River and three affluents, Rio Grande do Sul, studied between June 2001 and May 2002.

\begin{tabular}{llccc}
\hline Point & Sites & $\begin{array}{c}\text { Degree of } \\
\text { canopy } \\
\text { cover }\end{array}$ & $\begin{array}{c}\text { Degree of } \\
\text { anthropic } \\
\text { influence }\end{array}$ & $\begin{array}{c}\text { Degree of } \\
\text { turbidity }\end{array}$ \\
\hline Point 1 & Jacuí River & 1 & 3 & 2 \\
Point 2 & Lajeado do Gringo & 2 & 3 & 1 \\
Point 3 & Lajeado da Gringa & 2 & 2 & 1 \\
Point 4 & Carijinho River & 3 & 1 & 1 \\
\hline
\end{tabular}

natural logarithms, and by Pielou's Evenness Index (Magurran, 1989; Krebs, 1999) using the program Biodiversity Pro (McAlEecE et al., 1997).

The cumulative genera richness was calculated as the mean collector curve, based on 100 curves generated by random addition from the samples. The analysis was made for each point and for the total area using the program EstimateS, version 7.0 (CoLwell, 2004). This method was chosen to smooth the curve (Colwell \& CodDington, 1994). Rarefaction curves were built for each point based on Hurlbert (1971) and SimberLOFF (1972). The number of genera was estimated for 1,177 individuals, the smallest number of individuals among the four points, and the mean was estimated based on 1,000 iterations, with the help of the program EcoSim 700 (Gotelli \& ENTSMINGER, 2001). The Mann-Whitney test (U; ZAR, 1999) was utilized to compare the total Trichoptera abundance between two distinct periods of the year a priori by the abundance distribution graphic: October to March and April to September. The genera richness among the sites was compared by variance analysis (One-way ANOVA) and a posteriori multiple comparisons by Dunnet (ZAR, 1999).

\section{RESULTS}

Twenty-five genera in nine families, with a total o 29,143 larvae, were collected (Tab. II). In Point 1, 20 genera were registered, and Itauara Müller, 1888 and Smicridea McLachlan, 1871 were the most abundant (64\% and 19\%, respectively). Point 2 had the largest abundance, 12,547 larvae, in 20 genera, of which Smicridea (56\%) and Itauara $(37 \%)$ were the most frequent. At Point 3, 10,237 larvae in 17 genera were collected, with Itauara representing $77 \%$ of the larvae. Point 4 had the lowest abundance, 1,177 specimens in 16 genera (Tab. II); Smicridea, with $83 \%$ of larvae, was the most abundant. In July 2001 no collection was made in this point because it was flooded.

Itauara and Smicridea comprised $90 \%$ of the total, the former with $54 \%$ and the second with $36 \%$. There was an alternation of the dominance of these genera among the points, as shown above.

Seasonally, the period with larger abundances was October to March $(\mathrm{U}=2.88 ; \mathrm{p}<0.01)$ (Fig. 2). Peaks

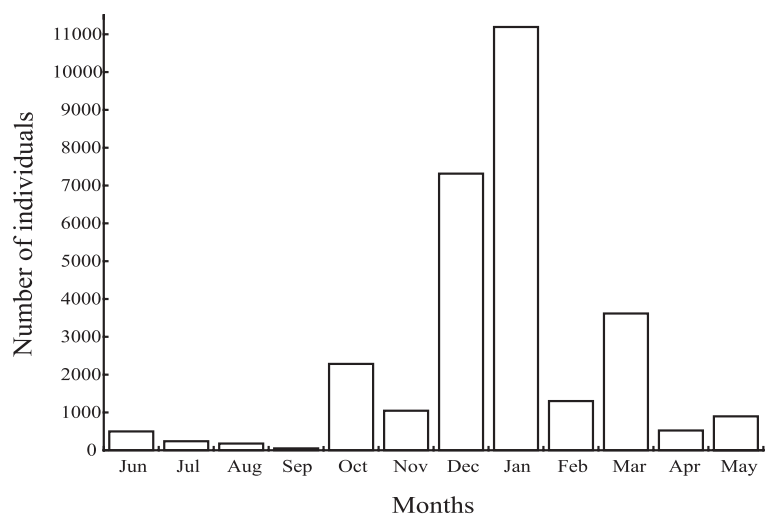

Fig. 2. Monthly variation of the total abundance of Trichoptera larvae, from June 2001 to May 2002, in the River Jacuí middle section and in three tributaries, State of Rio Grande do Sul. 
Table II. Taxonomic composition, functional feeding groups (FFG) and genera abundance of the Trichoptera larvae communities in the Jacuí River and tree affluents (RS), sampled between June 2001 and May 2002 (C, collector; Sc, scraper; Sh, shredder; P, predator; Pi, piercing).

\begin{tabular}{|c|c|c|c|c|c|}
\hline Taxa & FFG & Point 1 & Point 2 & Point 3 & Point 4 \\
\hline \multicolumn{6}{|l|}{ HYDROPSYCHIDAE } \\
\hline Blepharopus Kolenati, 1859 & $\mathrm{C}$ & 0 & 0 & 0 & 5 \\
\hline Macronema Pictet, 1836 & $\mathrm{C}$ & 13 & 2 & 0 & 12 \\
\hline Synoestropsis Ulmer, 1905 & $\mathrm{C}$ & 8 & 14 & 0 & 0 \\
\hline Smicridea McLachlan, 1871 & $\mathrm{C}$ & 969 & 6,990 & 1,699 & 972 \\
\hline \multicolumn{6}{|l|}{ POLYCENTROPODIDAE } \\
\hline Cernotina Ross, 1938 & $\mathrm{P}$ & 9 & 5 & 1 & 16 \\
\hline Cyrnellus Banks, 1913 & $\mathrm{C}$ & 1 & 28 & 1 & 16 \\
\hline Polyplectropus Ulmer, 1905 & $\mathrm{C}$ & 78 & 110 & 31 & 1 \\
\hline \multicolumn{6}{|l|}{ GLOSSOSOMATIDAE } \\
\hline Itauara Müller, 1888 & $\mathrm{Sc}$ & 3,296 & 4,629 & 7,915 & 18 \\
\hline Mexitrichia Mosely, 1937 & $\mathrm{Sc}$ & 0 & 0 & 161 & 2 \\
\hline Protoptila Banks, 1904 & $\mathrm{Sc}$ & 14 & 12 & 182 & 1 \\
\hline \multicolumn{6}{|l|}{ HYDROPTILIDAE } \\
\hline Hydroptila Dalman, 1819 & $\mathrm{Sc} / \mathrm{Pi}$ & 246 & 306 & 8 & 34 \\
\hline Oxyethira Eaton, 1873 & $\mathrm{Pi} / \mathrm{Sc}$ & 0 & 1 & 0 & 3 \\
\hline Abtrichia Mosely, 1939 & $\mathrm{Sc}$ & 64 & 35 & 3 & 68 \\
\hline Ceratotrichia Flint, 1992 & $\mathrm{Sc}$ & 35 & 0 & 0 & 0 \\
\hline Leucotrichia Mosely, 1934 & $\mathrm{Sc}$ & 0 & 0 & 3 & 8 \\
\hline Neotrichia Morton, 1905 & $\mathrm{Sc}$ & 42 & 43 & 10 & 9 \\
\hline Metrichia Ross, 1938 & $\mathrm{Pi}$ & 5 & 30 & 6 & 1 \\
\hline Ochrotrichia Mosely, 1934 & $\mathrm{Sc}$ & 94 & 12 & 0 & 0 \\
\hline \multicolumn{6}{|l|}{ CALAMOCERATIDAE } \\
\hline Phylloicus Müller, 1880 & Sh & 5 & 0 & 2 & 0 \\
\hline \multicolumn{6}{|l|}{ LEPTOCERIDAE } \\
\hline Nectopsyche Müller, 1879 & $\mathrm{Sh} / \mathrm{C}$ & 76 & 33 & 3 & 11 \\
\hline Grumichella Müller, 1879 & $\mathrm{Sc}$ & 25 & 1 & 0 & 0 \\
\hline Triplectides Kolenati, 1859 & $\mathrm{Sh}$ & 0 & 3 & 0 & 0 \\
\hline \multicolumn{6}{|l|}{ ODONTOCERIDAE } \\
\hline Marilia Müller, 1880 & Sh & 2 & 12 & 2 & 0 \\
\hline \multicolumn{6}{|l|}{ PHILOPOTAMIDAE } \\
\hline Chimarra Stephens, 1829 & $\mathrm{C}$ & 158 & 196 & 187 & 0 \\
\hline \multicolumn{6}{|l|}{ HELICOPSYCHIDAE } \\
\hline Helicopsyche Siebold, 1856 & $\mathrm{Sc}$ & 43 & 85 & 22 & 0 \\
\hline Total & & 5,183 & 12,547 & 10,236 & 1,177 \\
\hline Relative abundance & & $18 \%$ & $43 \%$ & $35 \%$ & $4 \%$ \\
\hline
\end{tabular}

occurred in December at Point 1, January at Points 2 and 3, and October at Point 4 (Fig. 3).

There was significant difference among sites regarding genera richness and total abundance $(\mathrm{F}=4.99$; $\mathrm{H}=10.23$ and $\mathrm{p}<0.01$, respectively). Point 4 had the lowest richness and abundance $(\mathrm{p}<0.05)$. Points 1 and 2 presented the largest genera richnesses, while points 2 and 3 had the largest abundance ( $p<0.05)$. Points 3 and 1 did not present significant difference to the other sites regarding richness and abundance $(p>0.05)$, respectively (Tabs. II, III).

Hydroptilidae had the greatest number of genera (8) representing $32 \%$ of the total number of genera collected, followed by Hydropsychidae, with four genera and $16 \%$ of the total. Calamoceratidae, Helicopsychidae, Odontoceridae and Philopotamidae, presented a single genus (Tab. II).

Collector curves, estimated for the four points, indicate that asymptotes were not attained; the curve of
Point 1 , although showing a trend to stabilization, still had a large confidence interval (Fig. 4). The collector curve for all points, however, stabilized from April on wards, presenting a null confidence interval, indicating that the asymptote was reached and that the effort was adequate to sample the assemblage of Trichoptera larvae in the area (Fig. 5).

Table III. Richness and diversity index (H'), Hmax and equity (e) for the four sampled stations and the total of the site in the Jacuí River middle section and tributaries (RS), registered from June 2001 to May 2002. The highest values are in bold.

\begin{tabular}{lccccc}
\hline Index & Point 1 & Point 2 & Point 3 & Point 4 & Total \\
\hline Richness & 20 & 20 & 17 & 16 & 25 \\
Shannon-Wiener & $\mathbf{1 . 3 1}$ & 1.04 & 0.77 & 0.83 & 1.14 \\
$\quad\left(H^{\prime}\right)$ ln & & & & & \\
Hmax ln & 3.00 & 3.00 & 2.83 & 2.77 & $\mathbf{3 . 2 2}$ \\
Equity (e) & $\mathbf{0 . 4 4}$ & 0.35 & 0.27 & 0.30 & 0.35 \\
\hline
\end{tabular}



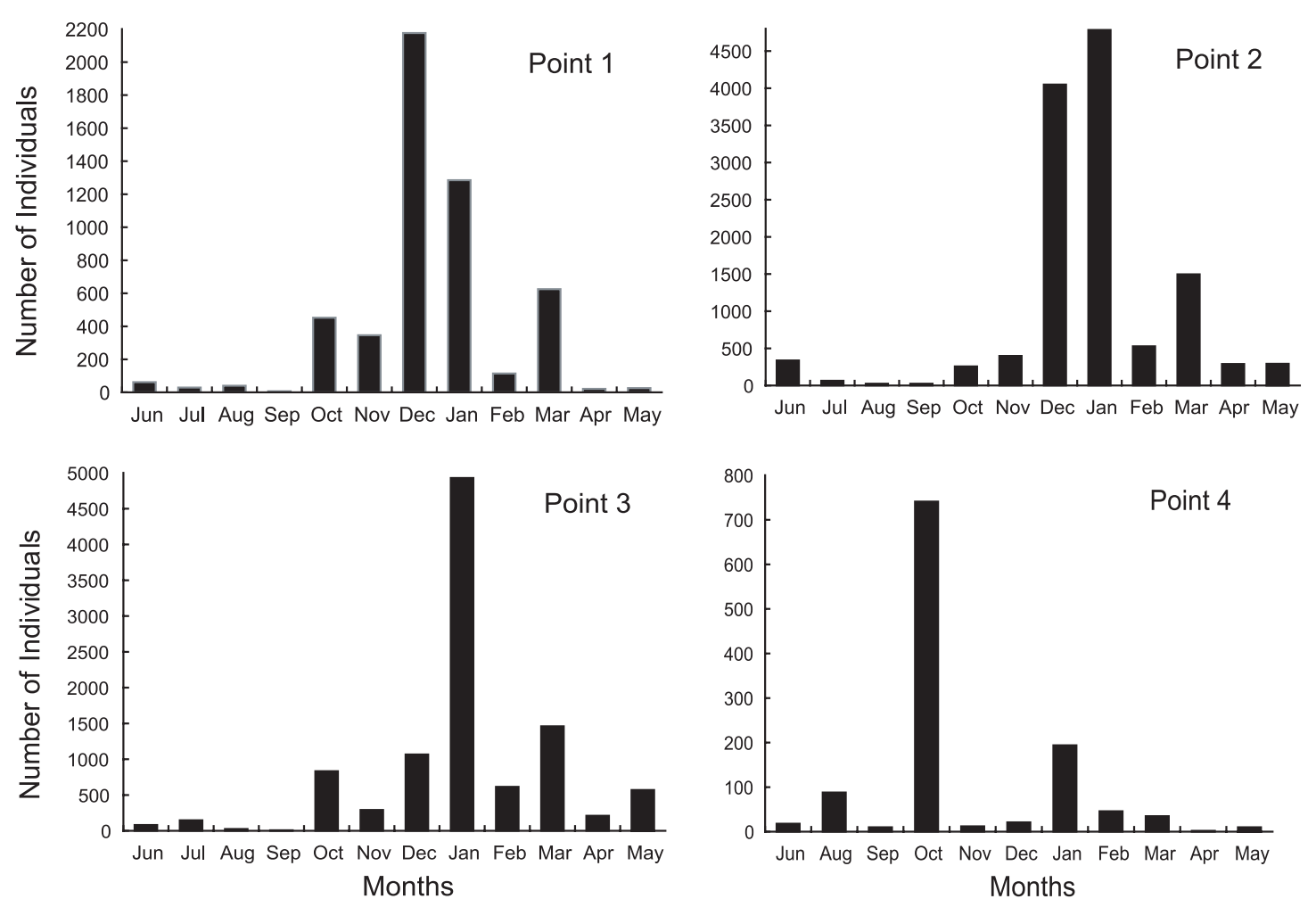

Fig. 3. Monthly variation of the abundance of Trichoptera larvae, by sampling point, from June 2001 to May 2002, in the River Jacuí middle section and in three tributaries, State of Rio Grande do Sul.
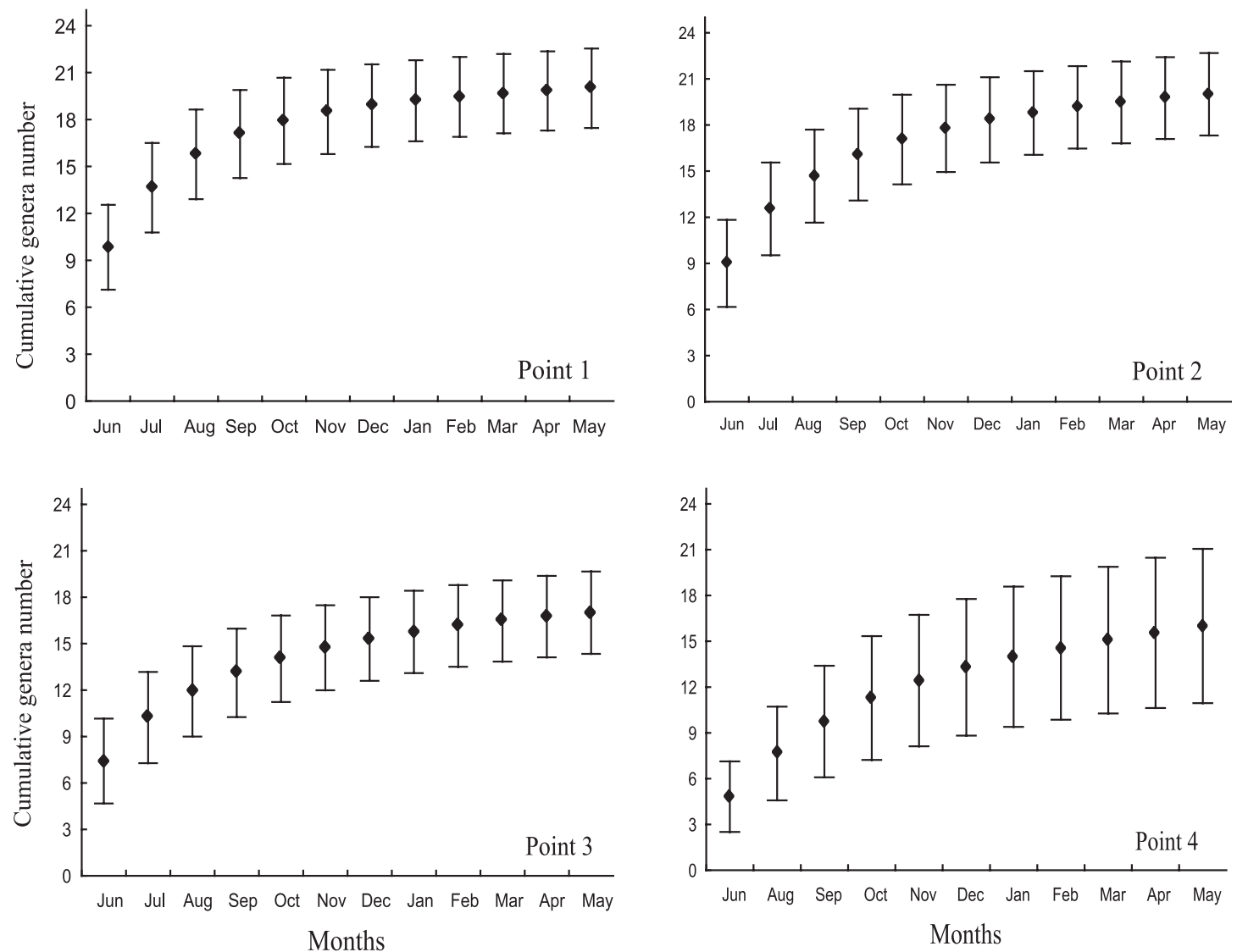

Fig. 4. Curves of accumulation of genera for the four studied points in the Jacuí River, State of Rio Grande do Sul, built from data obtained between June 2001 and May 2002. Each point express an average from 100 points generated by EstimateS version 7.0, the level bars indicate confidence intervals $(95 \%)$ computed for each point. 
Table IV. Comparative table of Trichoptera larvae genera richness in some Brazilian streams sampled riffles with Surber sampler: the river order is stated.

\begin{tabular}{|c|c|c|c|c|}
\hline Author & Water sites & $\begin{array}{c}\text { River hydrology } \\
\text { classification }\end{array}$ & $\begin{array}{c}\text { Number of } \\
\text { taxa }\end{array}$ & Abundance \\
\hline OLIVEIRA \& Froehlich (1997b) & Córrego Pedregulho, Pedregulho, SP & 4 th order & 10 & 5,631 \\
\hline Huamantinco \& Nessimian (1999) & Rio Paquequer, Teresópolis, RJ & 1st order & 14 & 219 \\
\hline OLIVEIRA \& BisPo (2001) & Córrego do Inferno, Pirenópolis, GO & 1st order & 24 & 2,048 \\
\hline OLIVEIRA \& Bispo (2001) & Córrego Vagafogo, Pirenópolis, GO & 1st order & 24 & 3,475 \\
\hline This work & Rio Carijinho, Arroio do Tigre, RS & 4 th order & 20 & 5,183 \\
\hline This work & Lajeado da Gringa, Ibarama, RS & 3 rd order & 20 & 12,547 \\
\hline This work & Lajeado do Gringo, Ibarama, RS & 4 th order & 17 & 10,236 \\
\hline This work & Rio Jacuí, Agudo, RS & 7 th order & 16 & 1,177 \\
\hline
\end{tabular}

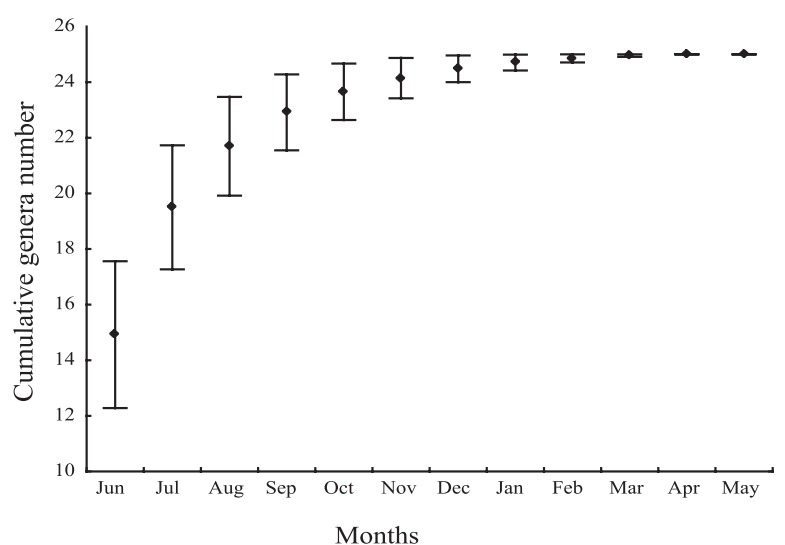

Fig. 5. Curve of accumulation of genera for the full site, Jacuí River and tree affluents, Rio Grande do Sul, built from data obtained between June 2001 and May 2002. The level bars indicate confidence intervals $(95 \%)$ computed for each point.

The richness estimated by rarefaction for the four points, for a sample of 1,177 individuals, showed that Point 1 had the largest value (17.7 genera), followed by Points 4 and 2 (16 and 14.6 genera, respectively), and with a much lower value, Point 3 (10.3 genera) (Figs. 6, 7).

Point 1 showed the largest Shannon-Wiener's diversity and Pielou's evenness indices and Point 3 the lowest ones. For the sum of the four points, the diversity was 1.14 and the evenness 0.35 (Tab. III).

\section{DISCUSSION}

In Brazil, 66 genera of Trichoptera in 16 families are known to occur (PES \& HAMADA, 2003, 2004; PAPROCKI et al., 2004; Holzenthal \& Pes, 2004; Huamantinco \& Nessimian, 2004, BLAHNIK, 2005). An additional undescribed genus is referred to in PES et al. (2005). In the study area, nine families and 25 genera were found. From the State of Rio Grande do Sul, only six genera were previously reported (STERNERT et al., 2002; PAPROCKI et al., 2004), of which five were found in the study area: Nectopsyche Müller, 1879, Oxyethira Eaton, 1873, Polyplectropus Ulmer, 1905, Phylloicus Müller, 1880 and Synoestropsis Ulmer, 1905. For the neighboring States of Santa Catarina and Paraná, the numbers are 24 and 36, respectively, showing the lack of surveys in Rio Grande do Sul in contrast to these states (e.g., Müller, 1880a,b; Almeida \& Marinoni, 2000; MARINONI \& AlmeIDA, 2000; BlahNIK et al., 2004).
Hydroptilidae is cosmopolitan, but especially diverse in the Neotropical Region, with both widely distributed and endemic genera (FLINT et al., 1999). With 22 genera, this is the most diversified family in Brazil (PES \& HAMADA, 2003, 2004; PAPROCKI et al., 2004), as was also in the study area, with eight genera. In number of genera, Hydroptilidae is followed by Leptoceridae (eight), Hydropsychidae (six), Polycentropodidae (five) and Glossosomatidae (four) (PAPROCKI et al., 2004). In the study area, Hydropsychidae was represented by four genera, followed by Glossosomatidae, Leptoceridae and Polycentropodidae, with three genera each. These differences may be due to the types of habitat sampled riffles. It may also explain the low diversification and abundance of the leptocerids, whose shredders larvae live mostly in pools (FLINT et al., 1999).

Hydropsychidae larvae are mainly collectors/ filterers (FLINT et al., 1999). Two subfamilies were found, Macronematinae and Smicrideinae. The first, with the genera Macronema Pictet, 1836, Blepharopus Kolenati, 1859 and Synoestropsis Ulmer, 1905, seems to be better adapted to larger rivers with warm waters. The second, with Smicridea, occurs from headwaters down to large rivers and may be locally very abundant (FLINT et al., 1999), which could explain the diversity and abundance of the family in the study area.

Communities in general have few abundant species and many rare species (ODuM, 2001). These patterns were corroborated in this study area, with dominance by the genera Itauara and Smicridea. The dominance patterns observed in the sampled points could possibly be explained by their physical characteristics, by the availability of food resources (MERRITT \& CUMMINs, 1996; Resh \& RosenBERG, 1984) and by the functional feeding groups (VANNOTE et al., 1980).

The feeding habits of Itauara are unknown, but it is probably a scraper, as the larvae live on stones in the current and are morphologically similar to the rest of the family (MerritT \& Cummins, 1996). Such scrapers feed mostly on periphyton, with its algae and associated microorganisms (Cummins \& KLUG, 1979). Points 1 and 3, where Itauara was dominant, had sparse vegetation cover, allowing good light incidence, stony bottom and were shallow; Point 3 , however, presented a larger canopy, which did not cover the river. This combination favors the development of periphyton (CUMmins \& KLUG, 1979) and, as a consequence, the high populations of Itauara. Smicridea larvae belong to the collectors/filterers 

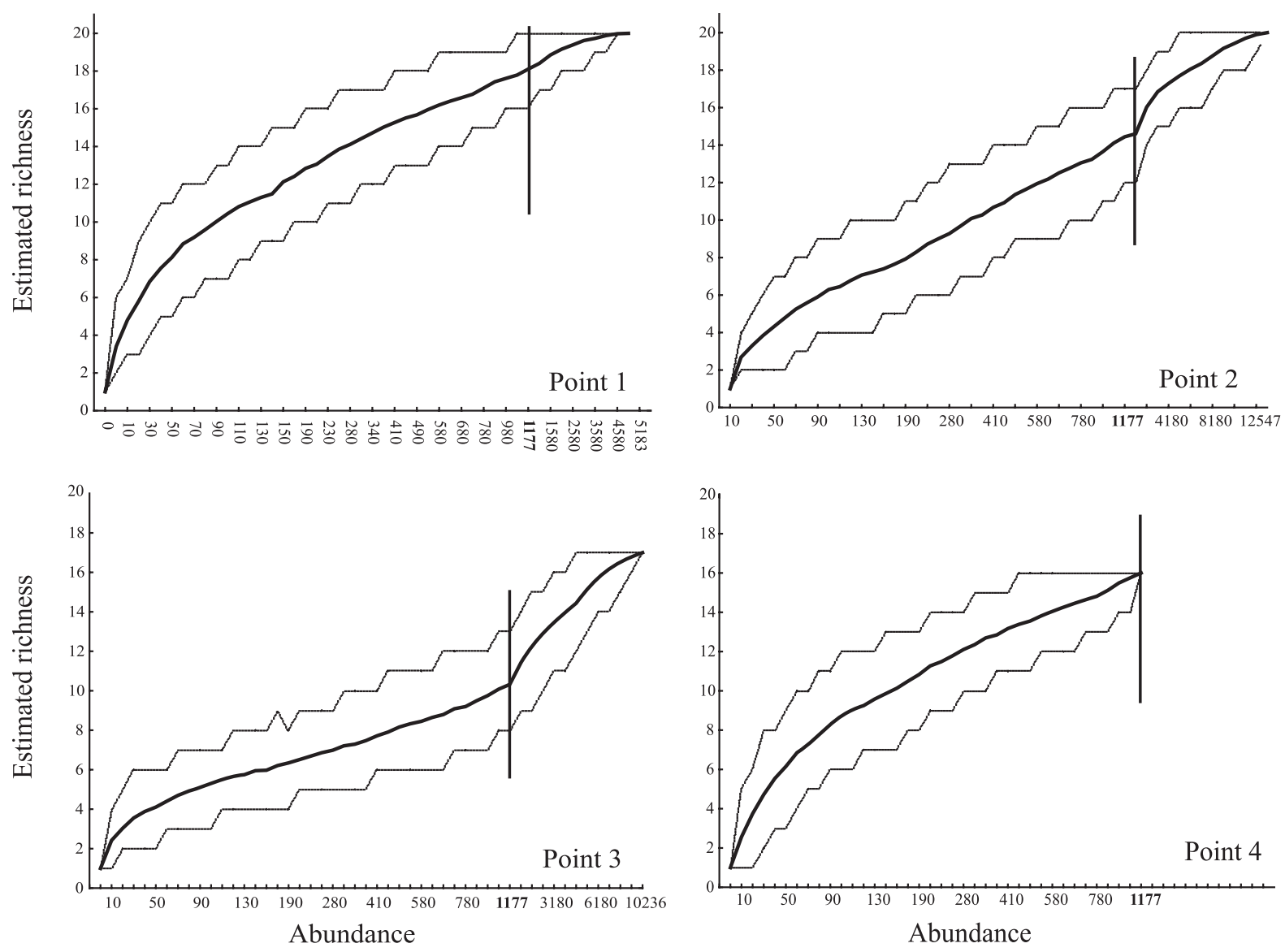

Fig. 6. Rarefaction curves of Trichoptera larvae genera registered between June 2001 and May 2002, for the four points, in the River Jacuí middle course and in the three tributaries, State of Rio Grande do Sul. The upper and lower lines indicate confidence intervals (95\%) computed for each point, and the bars represent a 1,177 - individuals sub-sample, except for Point 4, which refers to the whole sample.

category (Merritt \& Cummins, 1996; Oliveira \& FroeHLICH, 1996), they build capture nets facing the current and feed on the fine particulate organic matter (FPOM) caught. Besides detritus, this includes, diatoms, green algae and insect remnants (FLINT, 1974; Cummins \& Klug, 1979; Oliveira \& Froehlich, 1996; Wallace \& WeBster, 1996). FPOM prevails in large rivers, characterized by greater turbidity and poor light penetration (WIgGins \& MackAY, 1978). Collectors are common in rivers of all sizes but tend to be the main functional feeding groups in large ones (VANNOTE et al., 1980). The capture net of larval Smicridea has a mediumsized mesh allowing them to occupy almost all running water habitats (WIGGINs \& MACKAY, 1978). The great abundance of Smicridea, especially at points 2 and 4, may be due to the physical conditions of the points and the related food availability. At Point 4, where the largest numbers were observed, there is a large quantity of suspended particles (Tab. I), a condition that favors collectors (filterers) against scrapers, because the turbidity attenuates light penetration and restricts periphyton growth.

The monthly variation of the larvae abundances in the middle course of Jacuí River was strongly marked by high values from October to March (Fig. 2). These are the summer months where higher temperatures and

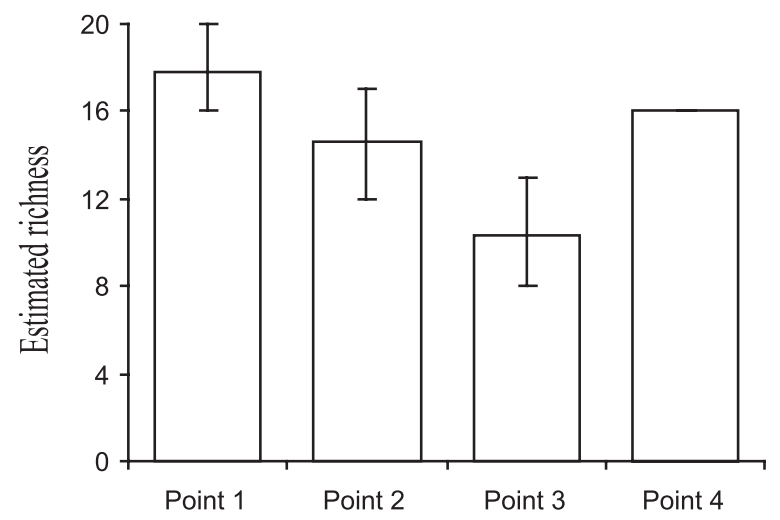

Fig. 7. Estimated richness comparison for 1,177 individuals sampled between June 2001 and May 2002 for the Trichoptera larvae assemblages in four studied sites in the Jacuí River and affluents, State of Rio Grande do Sul; for Points 1-3 the confidence intervals $(95 \%)$ are indicated.

insolation occur, which potentially promotes periphyton growth and offers more food to the larvae, specially for the scrapers.

The highest abundance occurred at Point 2, where both Smicridea and Itauara were numerous (Tab. II). This point is sunny and many stones are covered with 
macrophytes. These plants could offer good refuges for the former, whereas stones without macrophytes could have a large periphyton growth, good for the scrapers.

The low numbers recorded at Point 4 are probably related to the high turbidity and the sparse riparian cover. The high turbidity hinders the development of periphyton and the lack of riparian vegetation limits the influx of CPOM, conditions unfavorable to the development of populations of both scrapers and shredders (WIGGINs \& MACKAY, 1978). In addition, more sediment is found on the stones as a consequence of the large areas of land recently flooded by the dam. Melo \& Froenlich (2001) noticed that in two streams that had sediments on the rocks, the macroinvertebrate fauna was less rich and abundant.

Species (or taxa) accumulation curves are an excellent indicator of how efficiently a survey captures the total richness of an area. In tropical ecosystems, however, a curve rarely stabilizes, resulting in that more samplings are needed (SANTOS, 2003). Here, the curves had not stabilized but for the total value, suggesting that some genera found in one point could also occur in others. These results, of course, are valid only for riffles.

The comparison of richnesses by the rarefaction technique showed Point 1 to be the richest, followed by Point 4. This point, however, had the smallest number of genera. This result is probably due to the low number collected, as richness is strongly related to the number of individuals collected (Allan, 1995; MELo, 2003).

Comparing the results of the present study to other Brazilian streams (Tab. IV), the sampling method was the same, but the area sampled varied and, in some works, the subfamily Protoptilinae was not identified to genus. Comparing richness among 3rd and 4th order streams, those studied here (Points 1, 2 and 3) had larger richnesses. However, OliveIRA \& BISPO (2001), studying two 1 st order streams, found a larger richness of 24 genera in each, but with lower abundances. Point 4 ( 7 th order) cannot be compared to other studies but its richness is relatively high, as, according to VANNOTE et al. (1980), in higher order rivers richness should lower due to food constraints. This may be due to the stony substrate, and not, as in most larger rivers, soft bottoms made up of sand and/or silt. Taking the four points as a whole, the richness was comparable to those found in well preserved streams, e.g., 25 genera found by OLIVEIRA \& BISPO (2001).

Communities with highly dominant species are considered as less diverse (ODuM, 2001). Here, the highest diversity, that of Point 1 , is related to the highest evenness. Point 2, with the same richness, has lower evenness and diversity. The lowest evenness was that of Point 3, which, together with Point 2, have farms nearby and the riparian vegetation is poor, with some shrubs or only herbs. Point 4 had also a low evenness and is characterized by the quantity of sediments transported from upstream since the closure of the dam. The anthropic influence shows to be an important factor in reducing the diversity of Trichoptera by its destabilizing effect on ecosystems (Oliveira et al., 1997).

The diversity of genera of caddisfly larvae for the middle course of the Jacuí River was considered low, taking into account the theoretical maximum diversity
(Tab. III). Although no comparisons are possible, the use of diversity indices is important by their widespread use in environmental evaluations (e.g., CHARveT et al., 1998; RABENI et al., 1999). GOTELLI \& GRAVES (1996), however, criticized the joint consideration of both richness and relative abundance, suggesting that they be treated separately.

Some theories have been proposed to explain differences in richness and diversity in lotic environments (VANNOTE et al., 1980). According to the River Continuum Concept, they are related to the physical conditions of the river, which present a continuum of changes from the source down to the mouth. Maximum richness would be found in rivers of medium orders ( 3 rd and 4 th), where the environmental variability is larger, including the diversity of food resources and the daily variation in temperature (VANNOTE et al., 1980). Here, however, it is not possible to evaluate this concept because only a few areas of the river catchment were studied.

The highest richness and diversity found at Point 1 are probably related to the riparian vegetation and food availability. In this point the riparian vegetation is relatively well preserved, providing some shade and supplying CPOM. In addition, there are macrophytes growing on the rocks, making available refuges for animals living in the current. Carijinho River receives upstream a load of sewage but, running on a long and hilly stretch, arrives depurated at the sampling point.

In summary, the taxonomic composition of the four places studied in the Middle Jacuí River showed a high richness of genera, similar to that of preserved areas. There was a strong dominance of the genera Itauara and Smicridea, more of the former at Points 1 and 3 and of the latter at Points 2 and 4 . The highest standardized richness and diversity were found at Point 1 , the lowest at Point 3 . The study indicates that the Trichoptera communities are adjusted to the physical and biotic conditions, including food availability, riparian vegetation and anthropic influence, of the points studied.

Acknowledgments. To DFESA (Dona Francisca Energética S.A.), for financial support in the samplings. To CNPq (Conselho Nacional de Desenvolvimento Científico e Tecnológico), for student fellowship to the senior author. To the biologists Ana Emilia Siegloch and Damaris Neri Battistel, for assistance in sampling and sorting the material. To Prof. Dr. João Fernando Prado (UFSM), for macrophyte identification. To Dr. Ana Maria O. Pes for some Hydroptilidae (Leucotrichia, Ceratotrichia e Metrichia) identification. To Dr. Pitágoras Conceição Bispo (UNESP-Assis) and Dr. Leandro Gonçalves Oliveira (UFG), for critical reading and suggestions.

\section{REFERENCES}

Allan, J. D. 1995. Stream ecology: structure and function of running waters. New York, Chapman \& Hall. 388p.

Almeida, G. L. \& Marinoni, L. 2000. Abundância e sazonalidade das espécies de Leptoceridae capturadas em armadilha luminosa no Estado do Paraná. Revista Brasileira de Zoologia 17(2):347-359

Angrisano, E. B. 1993. Contribución al conocimiento del genero Antoptila Mosely (Trichoptera: Glossosomatidae). Revista de la Sociedad Entomologica Argentina 52:57-62.

1995a. Contribución para el conocimiento de las Oxyethira neotropicales (Trichoptera, Hydroptilidae). Physis, Sección B, 50(118-119):27-35.

1995b. Insecta Trichoptera. In: Lopretto, E. C. \& Tell, G. 
eds. Ecosistemas de águas continentales: metodologias para su estudio. La Plata, Sur. v. 3, p.1199-1237.

1998. Insecta Trichoptera. In: Morrone, J. J. \& Coscarón, S dirs. Biodiversidad de artrópodos argentinos: una perspectiva biotaxonómica. La Plata, Sur. p.374-384.

Angrisano, E. B. \& Korob, P. G. 2001. Trichoptera. In: Fernández, H. R. \& Domínguez, E. eds. Guía para determinación de los artrópodos bentónicos sudamericanos. San Miguel de Tucumán, Universidad Nacional de Tucumán. p.55-92.

Bispo, P. C.; Oliveira, L. G.; Crisci-Bispo, V. L \& Sousa, K. G. 2004 Environmental factors influencing distribution and abundance of trichopteran larvae in Central Brazilian mountain streams. Studies on Neotropical Fauna and Environment 39(3):233-237.

BlaHNik, R. J. 2005. Alterosa a new caddisfly genus from Brazil (Trichoptera: Philopotamidae). Zootaxa 991:1-60.

Blahnik, R. J.; Paprocki, H. \& Holzenthal, R. W. 2004. New distribution and species records of Trichoptera from southern and southeastern Brazil. Biota Neotropica 4(1): <http:// www.biotaneotropica.org.br/v4n1/pt/download?inventory+ BN01304012004>

Bueno, A. P.; Bond-Buckup, G. \& Ferreira, B. D. P. 2003. Estrutura da comunidade de invertebrados bentônicos em dois cursos d'água do Rio Grande do Sul, Brasil. Revista Brasileira de Zoologia 20(1):115-125.

Charvet, S.; Kosmala, A. \& Statzner, B. 1998. Biomonitoring through biological traits of benthic macroinvertebrates: perspectives for a general tool in stream management. Archiv für Hydrobiologie 142(4):415-423.

Colwell, R. K. 2004. EstimateS: statistical estimation of species richness and shared species from sample, Version 7.0. Available at: <http://viceroy.eeb.uconn.edu/ estimates>. Access on: 24.10.2004.

Colwell, R. K. \& Coddington, J. A. 1994. Estimating terrestrial biodiversity through extrapolation. Philosophical Transactions of the Royal Society of London, Series B, 345: $101-118$

Cummins, K. W. \& KLug, M. J. 1979. Feeding ecology of stream invertebrates. Annual Review of Ecology and Systematics 10:147-172

Diniz-Filho, J. A. F.; Oliveira, L. G. \& Silva, M. M. 1998. Explaining the beta diversity of aquatic insects in "cerrado" streams from central Brazil using multiple Mantel test. Revista Brasileira de Biologia 58(2):223-231.

Durlo, M. A.; Marchiori, J. N. C. \& Longhi, S. J. 1982. Composição e estrutura da mata secundária no vale do rio Jacuí, RS. Ciência e Natura (4):129-139.

Flint, O. S., JR. 1963. Studies of Neotropical caddis flies, I: Rhyacophilidae and Glossosomatidae (Trichoptera). Proceedings of the United States National Museum 114(3473): 453-478.

1972. Studies of Neotropical caddis flies, XIV: on a collection from northern Argentina. Proceedings of the Biological Society of Washington 85:223-248

1974. Studies of Neotropical caddisflies, XVIII: new species of Rhyacophilidae and Glossosomatidae (Trichoptera). Smithsonian Contributions to Zoology 169:1-30.

1982. Trichoptera of the area platense. Biologia Acuatica 2: $1-70$

Flint, O. S., JR. \& Bueno-Soria, J. 1982. Studies of Neotropical caddisflies XXXII: the immature stages of Macronema variipenne Flint \& Bueno, with the division of Macronema by the resurrection of Macrostemum (Trichoptera: Hydropsychidae). Proceedings of the Biological Society of Washington 95(2):358-370

Flint, O. S., JR. \& Wallace, J. B. 1980. Studies of Neotropical caddisflies XXV: the immature stages of Blepharopus diaphanus and Leptonema columbianum (Trichoptera: Hydropsychidae). Proceedings of the Biological Society of Washington 93(1): 178-193.

Flint, O. S., JR.; Holzenthal, R. W. \& Harris, S. C. 1999 Catalog of the neotropical caddisflies (Insecta: Trichoptera). Columbus, Ohio Biological Survey. 239p.

Gotelli, N. J. \& Entsminger, G. L. 2001. EcoSim: Null models software for ecology. Version 7.0. Acquired Intelligence Inc.
\& Kesey-Bear. Available at: <http://homepages.together.net/ $\sim$ gentsim/ecosim.htm>. Access on: 12.2005.

Gotelli, N. J. \& Graves, G. R. 1996. Null models in ecology. Washington, Smithsonian Institution. 368p.

Holzenthal, R. W. \& Pes, A. M. O. 2004. A new genus of longhorned caddisfly from the Amazon basin (Trichoptera: Leptoceridae: Grumichellini). Zootaxa 621:1-16.

Huamantinco, A. A. \& Nessimian, J. L. 1999. Estrutura e distribuição espacial da comunidade de larvas de Trichoptera (Insecta) em um tributário de primeira ordem do Rio Paquequer, Teresópolis RJ. Acta Limnologica Brasiliensia 11(2):1-16.

2004. A new genus and a new species of Odontoceridae (Trichoptera) from neotropics. Aquatic Insects 26(3/4):281-288.

Hurlbert, S. H. 1971. The nonconcept of species diversity: a critique and alternative parameters. Ecology 52:577-585.

Krebs, C. J. 1999. Ecological methodology. Menlo Park, Addison-Wesley Longman/Benjamin/Cummings. 620p.

Longhi, S. J.; Durlo, M. A. \& Marchiori, J. N. C. 1982. A vegetação da mata ribeirinha no curso médio do rio Jacuí, RS. Ciência e Natura (4):151-161.

Mackay, R. J. \& Wiggins, G. B. 1979. Ecological diversity in Trichoptera. Annual Review of Entomology 24:185-208.

Magurran, A. E. 1989. Ecological diversity and its measurement. London, Chapman and Hall. 179p.

Marchiori, J. N. C.; Longhi, S. J. \& Durlo, M. A. 1982. A vegetação de capoeira na região do curso médio do rio Jacuí, RS. Ciência e Natura (4):141-150.

Marinoni, L. \& Almeida, G. L. 2000. Abundância e sazonalidade das espécies de Hydropsychidae (Insecta, Trichoptera) capturadas em armadilha luminosa no Estado do Paraná. Revista Brasileira de Zoologia 17(1):283-299.

McAleece, N.; Lambsheah, P. J. D.; Paterson, G. L. J. \& Gage, J. G. 1997. Bio diversity professional. Beta-Version. London, The Natural History Museum and The Scottish Association for Marine Sciences.

Melo, A. S. 2003. Diversidade de macroinvertebrados em riachos. In: Cullen, L., JR.; Rudram, R. \& Valladares-Padua, C. orgs. Métodos de estudos em biologia da conservação e manejo da vida silvestre. Curitiba, UFPR/Fundação O Boticário. p.69-90.

Melo, A. S. \& Froehlich, C. G. 2001. Macroinvertebrates in neotropical streams: richness patterns along a catchment and assemblage structure between two seasons. Journal of the North American Benthological Society 20(1):1-16.

Merritt, R. W. \& Cummins, K. W. 1996. An introduction to the aquatic insects of North America. Iowa, Kendall/ Hunt. 862p.

MüllER, F. 1880a [1878]. Sobre as casas construidas pelas larvas de insectos Trichopteros da Provincia de Santa Catharina. Archivos do Museu Nacional, 3:99-134,210-214, plates 8-11.

1880b. Über die von den Trichopterenlarven der Provinz Santa Catharina verfertigen Gehäuse. Zeitschrift für Wissenschaftliche Zoologie 35:47-87.

Odum, E. P. 2001. Fundamentos de ecologia. Lisboa, Fundação Calouste Gulbenkian. 927p.

Oliveira, L. G. \& Bispo, P. C. 2001. Ecologia de comunidades das larvas de Trichoptera Kirby (Insecta) em dois córregos de primeira ordem da Serra dos Pireneus, Pirenópolis, Goiás, Brasil. Revista Brasileira de Zoologia 18(4):1245-1252.

Oliveira, L. G. \& Froenlich, C. G. 1996. Natural history of three Hydropsychidae in a "cerrado" stream from northeastern São Paulo. Revista Brasileira de Zoologia 13(3):755-762.

1997a. Diversity and community structure of aquatic insects (Ephemeroptera, Plecoptera and Trichoptera) in a southeastern Brazilian mountain stream. Acta Limnologica Brasiliensia 9:139-148.

1997b. The Trichoptera (Insecta) fauna of "cerrado" stream in southeastern Brazil. Naturalia 22:183-197.

Oliveira, L. G.; Bispo, P. C. \& Sá, N. C. 1997. Ecologia de comunidades de insetos bentônicos (Ephemeroptera, Plecoptera e Trichoptera), em córregos do Parque Ecológico de Goiânia, Goiás, Brasil. Revista Brasileira de Zoologia 14(4):867-876.

Oliveira, L. G.; Bispo, P. C.; Crisci, V. L. \& Sousa, K. G. 1999 Distribuições de categorias funcionais alimentares de larvas de Trichoptera em uma região serrana do Brasil Central. Acta Limnologica Brasiliensia 11(2):173-183. 
Paprocki, H.; Holzenthal, R. W. \& Blahnik, R. J. 2004. Checklist of the Trichoptera (Insecta) of Brazil I. Biota Neotropica 4(1): <http://www.biotaneotropica.org.br/v4n1/pt/download? inventory+BN01204012004>

Pereira, P. R. B.; Netto, L. R. G.; Borin, C. J. A. \& Sartori, M. G. B. 1989. Contribuição à geografia física do município de Santa Maria: unidades de paisagem. Geografia - Ensino e Pesquisa 3:37-68.

Pes, A. M. O. \& Hamada, N. 2003. The ocorrence of Taraxitrichia Flint \& Harris 1992 (Trichoptera: Hydroptilidae) in Brazil with description of the final larval stage. Zootaxa 328:1-7. . 2004. Ceratotrichia Flint, 1992 (Trichoptera: Hydroptilidae) larval and pupal description and a new genus records for Brazil. Entomotropica 19(1):31-37.

Pes, A. M. O.; Hamada, N. \& Nessimian, J. L. 2005. Chaves de identificação de larvas para famílias e gêneros de Trichoptera (Insecta) da Amazônia Central, Brasil. Revista Brasileira de Entomologia 49(2):181-204.

Rabeni, C. F; WANG, N. \& SARVER, R. J. 1999. Evaluating adequacy of the representative stream reach used in invertebrate monitoring programs. Journal of the North American Benthological Society 18(2):284-291.

Resh, V. H. \& Rosenberg, D. M. 1984. The ecology of aquatic insects. New York, Praeger. 625p.

Santos, A. J. Dos. 2003. Estimativas de riqueza em espécies. In: Cullen, L., JR.; Rudram, R. \& Valladares-Padua, C. orgs. Métodos de estudos em biologia da conservação e manejo da vida silvestre. Curitiba, UFPR/Fundação $O$ Boticário. p. 19-41.

Santos, E. M. dos; Stenert, C.; Oliva, T. D. \& Maltchik, L. 2003. Estabilidade de macroinvertebrados em uma lagoa associada a uma planície de inundação do Rio dos Sinos (RS - Brasil). Acta Biologica Leopoldensia 25(2):205-219.

Simberloff, D. 1972. Properties of the rarefaction diversity measurement. The American Naturalist 106:414-418.

Stenert, C. Santos, E. M. dos; Oliva, T. D. \& Maltchik, L. 2002. Diversidade de macroinvertebrados em áreas úmidas na bacia do rio dos Sinos, RS, Brasil. Acta Biologica Leopoldensia 24(2): 157-172.

Strahler, H. N. 1957. Quantitative analysis of watershed geomorphology. American Geophysical Union Transations 33:913-920.

Vannote, R. L.; Minshall, G. W.; Cummins, K. W.; Sedell, J. R. \& Cushing, C. E. 1980. The river continuum concept. Canadian Journal of Fisheries and Aquatic Sciences 37:130-137. Wallace, B. J. \& Webster, J. R. 1996. The role of macroinvertebrates in stream ecosystem function. Annual Review of Entomology 41:115-139.

Wiggins, G. B. 1996. Larvae of the North American caddisfly genera (Trichoptera). Toronto, University of Toronto. 401p.

Wiggins, G. B. \& Mackay, R. J. 1978. Some relationships between systematics and trophic ecology in Neartic aquatic insects, with special reference to Trichoptera. Ecology 59(6): 1211-1220

ZaR, J. H. 1999. Biostatistical Analysis. New Jersey, Prentice Hall. 663p. 